\title{
Storage of cuttings before and after grafting influences survival and vigor of vine grafts
}

\author{
Rafael Henrique Pertille ${ }^{1 *} \mathbb{D}$, Marcos Robson Sachet ${ }^{2}$, Marieli Teresinha Guerrezi ${ }^{2}$, \\ Chaiane Renata Grigolo ${ }^{1}$, Idemir Citadin ${ }^{1}$ \\ 10.1590/0034-737X202067060010
}

\begin{abstract}
Several grafting methods have been developed, and bench grafting with stratification is the most widely used technique, except in Brazil, which is still in adaptation. The objective of this study was to evaluate for how long plant material can be stored before the grafting and the optimum temperature for stratification. Cultivar 'Paulsen 1103' was used as rootstock and 'Niagara Rosada' as scion cultivar. The storage period treatments were 0, 30, 60 and 90 days at the temperature of $3{ }^{\circ} \mathrm{C}$ and $95 \%$ of relative humidity. After the storage period, the branches were removed from the cold chamber, taken to grafting, and then placed at $19{ }^{\circ} \mathrm{C}$ and $24{ }^{\circ} \mathrm{C}$ for stratification. After 21 days of stratification, the vine grafts were planted in commercial substrate and left to grow for 160 days. The vine cuttings of cultivars Niagara and Paulsen 1103 can be stored in cold chamber at $3{ }^{\circ} \mathrm{C}$ for 90 days and, during this period, bench grafting can be performed at any time. However, the vines from cuttings stored in cold chamber for more than 30 days have better growth. It is recommended to stratify the vine grafts at $19^{\circ} \mathrm{C}$.
\end{abstract}

Keywords: stratification; bench grafting; propagation; Vitis spp.

\section{INTRODUCTION}

The success of viticulture is directly related to the quality of the vine grafts used in the vineyard implantation. Among the several grafting techniques developed, the bench grafting with callus forcing, which was created in France in 1960, is the most widely used in grape producing countries, except in Brazil, where the technique is still in adaptation (Regina, 2002; Regina et al., 2012). The technique has been continuously studied and has been presenting satisfactory results in the production of quality vine grafts (Köse e Güleryüz, 2006; Korkutal et al., 2011; Regina et al., 2012; Maroli et al.,2014; Vršiè et al., 2015; Assunção et al., 2016). This technique involves a few steps that must be followed strictly, which are: collecting and preparing propagative material, cold storage in high humidity, grafting, forcing, and planting. However, important aspects of some of these steps have not yet been clarified for some scion/rootstock combinations, such as the storage time to overcome endodormancy and the temperature for callus forcing. The forcing stage ensures the success of the technique because of the great cell proliferation for the callus formation and for the tissues of the rootstock and the scion to grow together. A proper callus formation will result in a good vascular connection between the scion and the rootstock, ensuring plant survival (Bidabadi et al., 2018; Martínez-Ballesta et al., 2010). Thus, the objective of this study was to identify the optimum storage time and the optimum forcing temperature to produce quality vine grafts with satisfactory initial vegetative growth.

\section{MATERIAL AND METHODS}

The experiment was conducted in the experimental area of Universidade Tecnológica Federal do Paraná, Câmpus Pato Branco. The cultivar 'Paulsen 1103' (Vitis berlandieri $x$ Vitis rupestris) was used as rootstock and 'Niagara Ro-

Submitted on July 24th, 2019 and accepted on September 4th, 2020.

'Universidade Tecnológica Federal do Paraná, Programa de Pós-Graduação em Agronomia, Pato Branco, Paraná, Brazil. henriquepertille@gmail.com; chaigrigolo@hotmail.com; idemir@utfpr.edu.br

${ }^{2}$ Universidade Federal de Roraima, Campus Murupu, Boa Vista, Roraima, Brazil. marcos.sachet@ufrr.br; marieliguerrezi@hotmail.com

*Corresponding author: henriquepertille@gmail.com 
sada' (Vitis labrusca) as scion. Branches, with approximately $1 \mathrm{~m}$ length, of the rootstock and the scion were collected on May 20, 2016, from mother plants maintained at the Experimental Vine Station - EPAGRI, Santa Catarina. After the collection, the branches were kept in containers with the base submerged in water and later stored in a cold chamber at $95 \%$ humidity and temperature of $3{ }^{\circ} \mathrm{C}$.

The material was stored for $0,30,60$, and 90 days. At the end of each storage period, the branches were removed from the cold room and taken to the Fruit Laboratory to perform the grafting. The material was disinfected in sodium hypochlorite solution (1\%) for 10 minutes, then rinsed in tap water (three times), and sprayed with alcohol (70\%). Cuttings, 25 to $30 \mathrm{~cm}$ long, were taken from the branches of the rootstock with two to three buds and cut through its bottom end at $1 \mathrm{~cm}$ below the last bud and the top end at about $3 \mathrm{~cm}$ above the last bud. All rootstock buds were removed to avoid sprouting. The cuttings were grouped in blocks according to their diameter, in order to reduce the experimental error. Cleft grafting was performed by hand. The graft junction was wrapped with biodegradable paraffin tape (Buddy Tape ${ }^{\circledR}$ ) and sprayed with fungicide solution (Thiophanate methyl 20\%+ Chlorothalonil $50 \%-2 \mathrm{~g} / \mathrm{L}$ ). The top $2 / 3$ of the grafts were wrapped in newspaper paper and placed in plastic containers, with the basal ends of the grafts immersed in water to up to $1 / 3$ of their height.

The vine grafts were placed in controlled temperature chambers and kept in the dark for 21 days for forcing at a temperature of $19^{\circ} \mathrm{C}$ or $24^{\circ} \mathrm{C}$, with relative humidity around $90 \%$. After stratification, the basal ends of the grafts were dipped in 2000 ppm indolebutyric acid (IBA) solution for five seconds, planted in pots containing commercial substrate, and kept in greenhouse under drip irrigation for 160 days. The initial sprouting was monitored using the BBCH phenological scale (Lorenz et al., 1994), up to 70 days after planting. At 160 days after transferring the grafts to the greenhouse, the evaluation of survival and destructive analysis of the grafts was carried out for each treatment. The variables evaluated were root number, root length, shoot length, leaf area, shoot dry mass, and root dry mass. The leaf area was measured with a leaf area integrator (LI-COR, model LI-3100C). The experiment was arranged in a $4 \times 2$ factorial (storage time and stratification temperature) randomized block design, with four replicates. The experimental units consisted of 20 grafts, totaling 640 grafts. Data were analyzed by Anova and the Tukey's test. The assumptions of the Anova were evaluated by tests and graphically, and the variables survival and leaf area were transformed. All analyzes were performed in R language version 3.6.0 (R Core Team, 2019) with the package ExpDes.pt v. 1.2.0 (Ferreira et al., 2018).

\section{RESULTS}

No significant interaction was found between storage times and stratification temperatures for survival percentage and number of roots (Table 1). Survival rates were high in all treatments (78.1 to 85\%), with no difference between the storage time. For forcing temperatures, survival was higher when grafts were kept at $19^{\circ} \mathrm{C}(89.4 \%)$ than at $24{ }^{\circ} \mathrm{C}(72.8 \%)$. Number of roots was most favored by the storage time of 60 days, but do not differ from 30 days. The highest number of roots was recorded at the forcing temperature of $19^{\circ} \mathrm{C}$.

Shoot and root length were the longest in the treatment at forcing temperature of $19{ }^{\circ} \mathrm{C}$, in the storage time of 90 days (Table 2). Root length in the storage time of 90 days not differ from 60 days treatment. However, at $24{ }^{\circ} \mathrm{C}$, the storage time of 60 days contributed the most to the root and shoot length, but in shoot length the storage time of 60 days do not differ from 30 days and 90 days. At 90 days of storage, the forcing of the grafts at $19{ }^{\circ} \mathrm{C}$ allowed a much superior shoot growth than the grafts subjected to forcing temperature of $24^{\circ} \mathrm{C}$. The variables leaf area, shoot dry mass, and root dry mass had a similar behavior to the variables shoot length and root length, and had significant interaction between storage times and stratification temperatures (Table 3). The greatest leaf area, shoot dry mass, and root dry mass were found for the treatment 90 days of storage and forcing temperature of $19^{\circ} \mathrm{C}$, but in variables leaf area and root dry mass the 90 days of storage do not differ from 60 days. At the temperature of $24{ }^{\circ} \mathrm{C}$, the optimum storage periods for leaf area were 60 days and 30 days; for shoot dry mass was 60 days, do not differing from 30 days and 90 days; and for root dry mass was 60 days, do not differing from 30 days (Table 3 ).

The treatments 60 and 90 days of storage had a faster evolution of the phenological stages and reached a higher stage at 70 days after planting (Figure 1). Vine grafts that remained under the temperature of $24{ }^{\circ} \mathrm{C}$ in the forcing period had a higher phenological stage at the time of planting, but at 70 days after planting, both temperatures had close phenological stage means.

Table 1: Survival rates (S) and number of roots (NR) under different periods of storage and stratification temperatures

\begin{tabular}{lll}
\hline Period & $\mathbf{S}(\boldsymbol{\%})$ & NR \\
\hline 0 days & $85^{\mathrm{ns}}$ & $15.5 \mathrm{c}$ \\
30 days & 78.1 & $25.2 \mathrm{ab}$ \\
60 days & 81.3 & $30.8 \mathrm{a}$ \\
90 days & 80 & $21.1 \mathrm{bc}$ \\
\hline $19^{\circ} \mathrm{C}$ & $89.4 \mathrm{a}$ & $26.7 \mathrm{a}$ \\
$24^{\circ} \mathrm{C}$ & $72.8 \mathrm{~b}$ & $19.6 \mathrm{~b}$ \\
\hline $\mathrm{CV}(\%)$ & 35.23 & 23.25 \\
\hline
\end{tabular}

* Means followed by different lower case letters in the column are significantly different by the Tukey's test $(\mathrm{p} \leq 0.05)$. 


\section{DISCUSSION}

The high percentages of survival for all storage periods of the cuttings show that the plant material can be stored for up to 90 days without reducing the survival of vine grafts. The lower survival rate at $24{ }^{\circ} \mathrm{C}$ may be due to the sprouting occurring already during the stratification. Sprouts might deplete the reserves of the cuttings and reduce the chance of root formation, not allowing allocation of resources to support the growth of shoots already formed. Maroli et al. (2014) found similar results working with cv. Bordô (Vitis labrusca)/Paulsen 1103, obtaining higher survival rate at $19{ }^{\circ} \mathrm{C}(75 \%)$ and lower at $24^{\circ} \mathrm{C}(67.5 \%)$. The excessive callus growth, due to the higher temperature, may also have contributed to the lower survival of the grafts. The survival rates in this study remained close to or higher than the means achieved by French nurseries that use bench grafting (Regina et al., 2012).

Table 2: Shoot length (SL) and root length (RL) under different periods of storage and stratification temperatures

\begin{tabular}{|c|c|c|c|c|}
\hline \multirow{2}{*}{ Period } & \multicolumn{2}{|c|}{ SL (cm) } & \multicolumn{2}{|c|}{ RL (cm) } \\
\hline & $19{ }^{\circ} \mathrm{C}$ & $24^{\circ} \mathrm{C}$ & $19^{\circ} \mathrm{C}$ & $24^{\circ} \mathrm{C}$ \\
\hline 0 days & $14.4 \mathrm{bA}^{*}$ & $11.7 \mathrm{bA}$ & $32.3 \mathrm{cA}$ & $40.2 \mathrm{bA}$ \\
\hline 30 days & $22.5 \mathrm{bA}$ & $23.7 \mathrm{abA}$ & $45.9 \mathrm{bcA}$ & $41.9 \mathrm{bA}$ \\
\hline 60 days & $40.9 \mathrm{bA}$ & $48.4 \mathrm{aA}$ & $58.2 \mathrm{abA}$ & $70.6 \mathrm{aA}$ \\
\hline 90 days & $81.1 \mathrm{aA}$ & $33.9 \mathrm{abB}$ & $77.1 \mathrm{aA}$ & $46.1 \mathrm{bB}$ \\
\hline$\overline{\mathrm{CV}}(\%)$ & \multicolumn{2}{|c|}{44.04} & \multicolumn{2}{|c|}{19.28} \\
\hline
\end{tabular}

* Means followed by different lower case letters in the column and capital letters in the row are significantly different by the Tukey's test ( $\mathrm{p} \leq 0.05)$.

Table 3: Mean leaf area (LA), shoot dry mass (SDM), and root dry mass (RDM) under different periods of storage and stratification temperatures

\begin{tabular}{|c|c|c|c|c|c|c|}
\hline & \multicolumn{2}{|c|}{$\mathbf{L A}\left(\mathbf{c m}^{2}\right)$} & \multicolumn{2}{|c|}{ SDM (g) } & \multicolumn{2}{|c|}{ RDM (g) } \\
\hline & $19^{\circ} \mathrm{C}$ & $24^{\circ} \mathrm{C}$ & $19^{\circ} \mathrm{C}$ & $24^{\circ} \mathrm{C}$ & $19{ }^{\circ} \mathrm{C}$ & $24^{\circ} \mathrm{C}$ \\
\hline 0 days & $253.1 \mathrm{cA}^{*}$ & $152.4 \mathrm{cB}$ & $8.9 \mathrm{cA}$ & $8.6 \mathrm{bA}$ & $8.8 \mathrm{cA}$ & $8.4 \mathrm{bA}$ \\
\hline 30 days & $347.3 \mathrm{bcA}$ & $362.2 \mathrm{aA}$ & $10.9 \mathrm{bcA}$ & $10.5 \mathrm{abA}$ & $11.7 \mathrm{bcA}$ & $12.5 \mathrm{abA}$ \\
\hline 60 days & $588.7 \mathrm{abA}$ & $598.5 \mathrm{aA}$ & $13.1 \mathrm{bA}$ & $13.2 \mathrm{aA}$ & $19.2 \mathrm{abA}$ & $19.5 \mathrm{aA}$ \\
\hline 90 days & $994.5 \mathrm{aA}$ & $204.3 \mathrm{bB}$ & $17.4 \mathrm{aA}$ & $9.6 \mathrm{abB}$ & $27.3 \mathrm{aA}$ & $11.0 \mathrm{bB}$ \\
\hline $\mathrm{CV}(\%)$ & \multicolumn{2}{|c|}{26.9} & \multicolumn{2}{|c|}{18.1} & \multicolumn{2}{|c|}{11.9} \\
\hline
\end{tabular}

*Means followed by different lower case letters in the column and capital letters in the row are significantly different by the Tukey's test $(\mathrm{p} \leq 0.05)$.

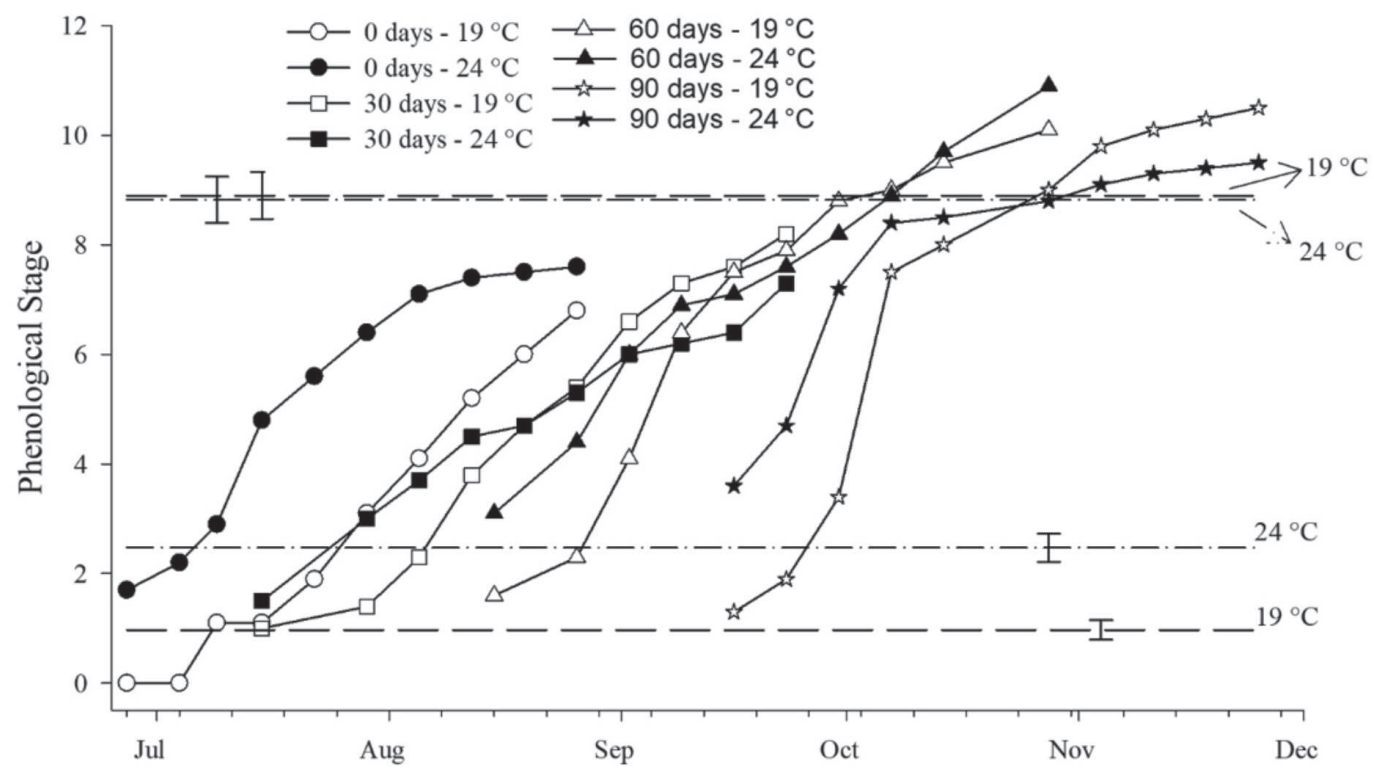

Figure 1: Evolution of the phenological stages up to seventy days after planting. Dashed lines represent the means of the stages for each stratification temperature. Error bars represent the standard errors of the means $(n=4)$. 


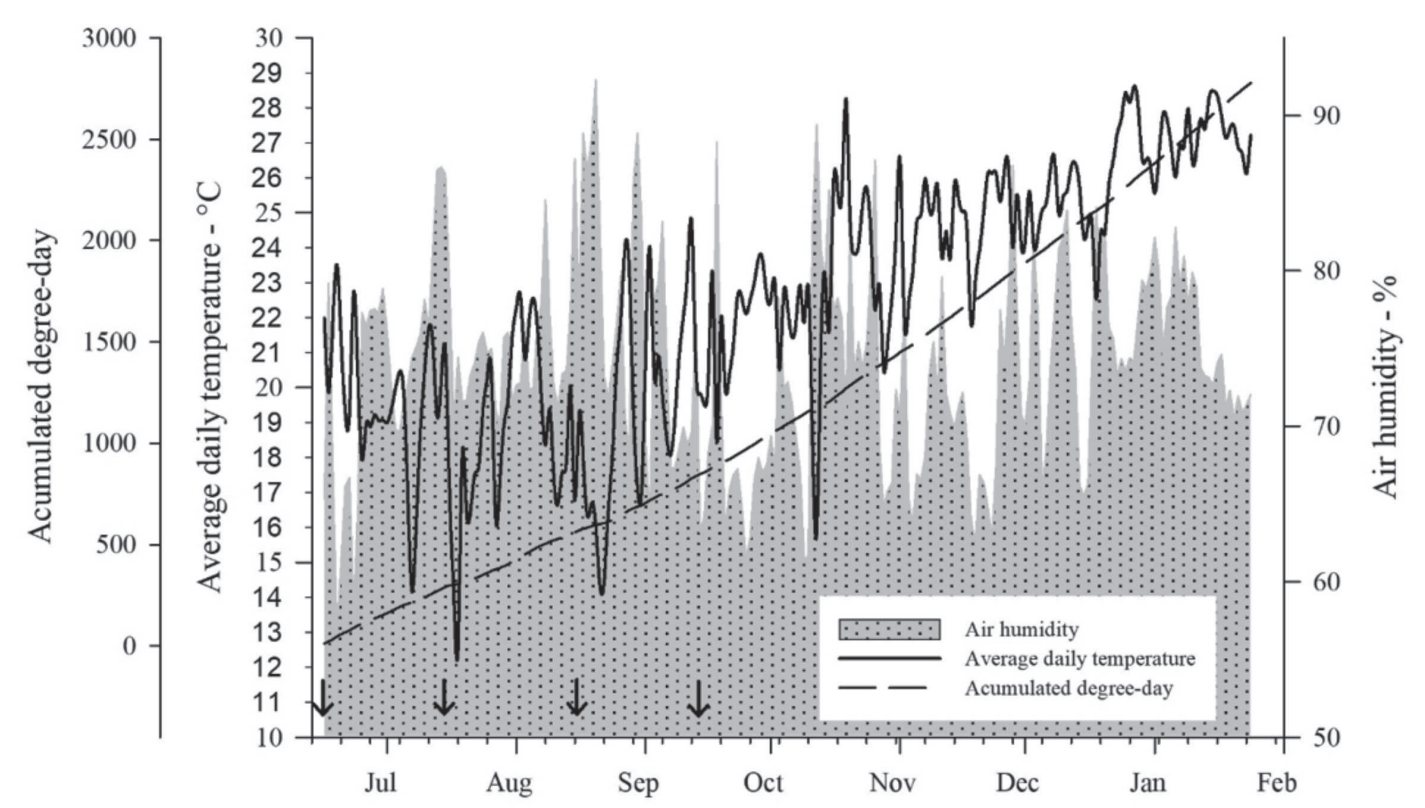

Figure 2: Average daily temperature, air humidity, and degrees day accumulated inside the greenhouse. Arrows indicate the entry date of each treatment.

The period of 90 days of storage favored chilling accumulation to break dormancy in the cuttings, but induction of sprouting occurred when stratified under the temperature of $24^{\circ} \mathrm{C}$. The partition of carbohydrate reserves to callusing, rooting, and sprouting decreased the initial growth of the plant. High temperatures can increase callus formation, which has negative correlation with root formation (Köse e Güleryüz, 2006).

The increase in the average temperature within greenhouse contributed to a better development of the grafts in the treatments of 60 and 90 days of storage. There are differences in the development of vine grafts depending on the time of grafting, with the greatest shoot and root growth being attributed to higher thermal sums accumulated after grafting (Maroli et al., 2014). Up to 130 days of development, the treatments 60 and 90 days of storage had accumulated 1665 and 1900 degrees-day, respectively, while the treatments 0 and 30 days of storage had accumulated 1314 and 1460 degrees-day, respectively (Figure 2).

The stratification temperature of $19{ }^{\circ} \mathrm{C}$ was better for all variables in the treatment 90 days of storage because of the early sprouting and excessive callusing at $24{ }^{\circ} \mathrm{C}$ during the stratification period, decreasing growth after planting. Sprouting during stratification must be prevented by removing the grafts from the stratification as soon as there is callus formation on the graft union, so the carbohydrate reserve in the cuttings is allocated to root formation before shoot formation, favoring the absorption of water and nutrients (Regina, 2002). It is evident that longer storage periods require lower stratification temperatures, whereas in shorter storage periods, the stratification temperature is not limiting for the growth of vine grafts.

\section{CONCLUSION}

'Niagara Rosada' and 'Paulsen 1103' grapevine cuttings can be stored in cold room for up to 90 days and, during this period, table grafting can be performed at any time; however.

The vine grafts from cuttings stored for more 30 days in a cold room have better development. It is recommended to stratify the vine grafts at $19^{\circ} \mathrm{C}$.

This protocol allows the scheduling of the grafting activity and the optimization of the work at the nursery.

\section{ACKNOWLEDGEMENTS, FINANCIAL SUPPORT AND FULL DISCLOSURE}

The authors would like to thank M.sc Lari Maroli for the support in the grafting procedure and the National Council for Scientific and Technological Development (CNPq) and Coordination for the Improvement of Higher Education Personnel (CAPES) for their financial support. The authors declare no conflicts of interest.

\section{REFERENCES}

Assunção M, Canas S, Cruz S, Brazão J, Zanol GC \& Eiras-Dias JE (2016) Graft compatibility of Vitis spp.: the role of phenolic acids and flavanols. Scientia Horticulturae, 207:140-145.

Bidabadi SS, Afazel M \& Sabbatini P (2018) Iranian grapevine rootstocks and hormonal effects on graft union, growth and antioxidant responses of Asgari seedless grape. Horticultural Plant Journal, 4:16-23. 
Ferreira EB, Cavalcanti PP \& Nogueira DA (2018) ExpDes.pt: Experimental Designs package (Portuguese). Version 1.2.0 Vienna, CRAN Repository, R Foundation for Statistical Computing. Available at: <https://cran.r-project.org/ package=ExpDes.pt $>$. Accessed on: January 1 1t, 2016.

Korkutal I, Kaygusuz G \& Bayram S (2011) Different effect of scion types on callusing in bench grafting. African Journal of Biotechnology, 10:15123-15129.

Köse C \& Güleryüz M (2006) Effects of auxins and cytokinins on graft union of grapevine (Vitis vinifera). New Zealand Journal Crop and Horticultural Science, 34:145-150.

Lorenz DH, Eichhorn KW, Bleiholder H, Klose R, Meier U \& Weber E (1994) Phänologische Entwicklungsstadien der Weinrebe (Vitis vinifera L. ssp. vinifera). Codierung und Beschreibung nach der erweiterten BBCH-Skala. WeinWissenschaft, 49:66-70.

Maroli L, Citadin I, Sachet MR, Scariotto S \& Junior AW (2014) Produção de mudas de videira cv. Bordô/Paulsen 1103 pela enxertia de mesa com estratificação. Revista Brasileira de Fruticultura, 36:673-679.
Martínez-Ballesta MC, Alcaraz-López C, Muries B, Mota-Cadenas C \& Carvajal M (2010) Physiological aspects of rootstockscion interactions. Scientia Horticulturae, 127:112-118.

R Development Core Team (2018) R: A language and environment for statistical computing. Vienna, R Foundation for Statistical Computing. Available at: 〈https://www.r-project.org〉. Accessed on: January $1^{\text {st }}, 2016$.

Regina MA (2002) Produção e certificação de mudas de videira na França 2. Técnica de produção de mudas pela enxertia de mesa. Revista Brasileira de Fruticultura, 24:590-596

Regina MA, Souza CR \& Dias FAN (2012) Propagação de Vitis spp. pela enxertia de mesa utilizando diferentes porta-enxertos e auxinas. Revista Brasileira de Fruticultura, 34:897-904.

Vršiè S, Pulko B \& Kocsis L (2015) Factors influencing grafting success and compatibility of grape rootstocks. Scientia Horticulturae, 181:168-173. 